\title{
Molecular Profiling of Mammary Analog Secretory Carcinoma Revealed a Subset of Tumors Harboring a Novel ETV6-RET Translocation: Report of 10 Cases
}

Skalova, Alena ; Vanecek, Tomas ; Martinek, Petr ; Weinreb, Ilan ; Stevens, Todd M ; Simpson, Roderick H W ; Hyrcza, Martin ; Rupp, Niels J ; Baneckova, Martina ; Michal, Michael ; Slouka, David ; Svoboda, Tomas ; Metelkova, Alena ; Etebarian, Arghavan ; Pavelka, Jaroslav ; Potts, Steven J ;

Christiansen, Jason ; Steiner, Petr ; Michal, Michal

DOI: https://doi.org/10.1097/PAS.0000000000000972

Posted at the Zurich Open Repository and Archive, University of Zurich ZORA URL: https://doi.org/10.5167/uzh-144887

Journal Article

Published Version

Originally published at:

Skalova, Alena; Vanecek, Tomas; Martinek, Petr; Weinreb, Ilan; Stevens, Todd M; Simpson, Roderick H W; Hyrcza, Martin; Rupp, Niels J; Baneckova, Martina; Michal, Michael; Slouka, David; Svoboda, Tomas; Metelkova, Alena; Etebarian, Arghavan; Pavelka, Jaroslav; Potts, Steven J; Christiansen, Jason; Steiner, Petr; Michal, Michal (2018). Molecular Profiling of Mammary Analog Secretory Carcinoma Revealed a Subset of Tumors Harboring a Novel ETV6-RET Translocation: Report of 10 Cases. American Journal of Surgical Pathology, 42(2):234-246.

DOI: https://doi.org/10.1097/PAS.0000000000000972 


\title{
Molecular Profiling of Mammary Analog Secretory Carcinoma Revealed a Subset of Tumors Harboring a Novel ETV6-RET Translocation Report of 10 Cases
}

\author{
Alena Skalova, MD, PhD, *† Tomas Vanecek, PhD, $\neq$ Petr Martinek, PhD, $\neq$ Ilan Weinreb, MD, $\S$ \\ Todd M. Stevens, PhD, $\|$ Roderick H.W. Simpson, MD, MB, ChB, FRCPath, $\|$ \\ Martin Hyrcza, MD, PhD,\# Niels J. Rupp, MD,** Martina Baneckova, MD, *广 \\ Michael Michal, Jr, MD, ${ }^{* \dagger}+$ David Slouka, MD, MBA, PhD, $+\neq$ Tomas Svoboda, MD, PhD, $\S \S$ \\ Alena Metelkova, MD, PhD,\|\| Arghavan Etebarian, DDS, OMP, $\| \rrbracket$ \\ Jaroslav Pavelka, PhD, \#\#\# Steven J. Potts, PhD,*** Jason Christiansen, PhD,*** \\ Petr Steiner, MSc, $*$ and Michal Michal, MD*
}

\begin{abstract}
ETV6 gene abnormalities are well described in tumor pathology. Many fusion partners of ETV6 have been reported in a variety of epithelial, mesenchymal, and hematological malignancies. In salivary gland tumor pathology, however, the ETV6-NTRK3 translocation is specific for (mammary analog) secretory carcinoma, and has not been documented in any other salivary tumor type. The present study comprised a clinical, histologic, and molecular analysis of 10 cases of secretory carcinoma, with typical morphology and immunoprofile harboring a novel ETV6-RET translocation.
\end{abstract}

From the Departments of *Pathology; \$Otorhinolaryngology; \$\$Oncology and Radiotherapy, Oncological Clinic; \|\|Clinical Oncology, Oncological Clinic, Faculty of Medicine in Plzen; † Biomedical Center, Faculty of Medicine in Pilsen, Charles University; $\dagger$ Bioptic Laboratory Ltd; †Bioptic Laboratory Ltd, Molecular Pathology Laboratory; \#\#Faculty of Education, University of West Bohemia, Plzen, Czech Republic; \$Department of Pathology, University Health Network, Toronto, ON, Canada; \#Department of Pathology, University of Alabama at Birmingham, Birmingham, AL; Department of Anatomical Pathology, University of Calgary and Foothills Medical Centre, Calgary, AB; \#Department of Pathology and Molecular Medicine, St. Joseph's Healthcare \& Hamilton Health Sciences, McMaster University, Vancouver, BC, Canada; **Department of Pathology and Molecular Pathology, University Hospital Zurich, Zurich, Switzerland; q1Department of Oral and Maxillofacial Pathology, School of Dentistry, Tehran University of Medical Sciences, Tehran, Iran; and ***Ignyta Inc. San Diego, California, United States.

Conflicts of Interest and Source of Funding: Supported in parts by the National Sustainability Program I (NPU I) Nr. LO1503 and by the grant SVV-2017 No. 260391 provided by the Ministry of Education Youth and Sports of the Czech Republic. The NGS analysis was in part supported by Ignyta Inc., San Diego, CA. The authors have disclosed that they have no significant relationships with, or financial interest in, any commercial companies pertaining to this article.

Correspondence: Alena Skalova, MD, PhD, Sikl's Department of Pathology, Medical Faculty of Charles University, Faculty Hospital, E. Benese

13, Plzen 305 99, Czech Republic (e-mail: skalova@fnplzen.cz).

Copyright (C) 2017 Wolters Kluwer Health, Inc. All rights reserved.
Key Words: salivary, mammary analog secretory carcinoma, MASC, ETV6-NTRK3, ETV6-RET fusion transcript

(Am J Surg Pathol 2017;00:000-000)

(M ammary analog) secretory carcinoma of salivary gland origin is a recently described tumor that harbors a characteristic balanced $\mathrm{t}(12 ; 15)(\mathrm{p} 13 ; \mathrm{q} 25)$ chromosomal translocation resulting in an ETV6-NTRK3 fusion $^{1}$ identical to that commonly found in secretory carcinoma (SC) of the breast. ${ }^{2}$ The ETV6-NTRK3 fusion gene encodes a chimeric tyrosine kinase with transforming activity in epithelial and myoepithelial cells in the mouse mammary gland. ${ }^{3}$

Over many years, Skalova et $\mathrm{al}^{1}$ began to identify a distinctive, hitherto unrecognized neoplasm arising in the salivary glands characterized by morphologic and immunohistochemical features strongly reminiscent of those of SC of the breast. These salivary carcinomas are composed of microcystic and solid areas with abundant vacuolated colloid-like periodic acid-Schiff-positive secretory material within the microcystic spaces. These tumors had previously been categorized as either unusual variants of salivary acinic cell carcinoma (AciCC) or adenocarcinoma not otherwise specified. ${ }^{1}$

Salivary SC was initially recognized as an entity different from AciCC on the basis of 3 major findings. ${ }^{1}$ First, SC showed no basophilia in the cytoplasm of any of the constituent cells, which is the hallmark of the serous acinar cells of AciCC resulting from the presence of cytoplasmic zymogen granules. Second, these neoplasms had a completely different immunohistochemical profile, almost always expressing S100 protein, mammaglobin, vimentin, STAT5, and MUC4, all of which are rarely expressed in AciCC. Finally, SCs were found to harbor an 
TABLE 1. Antibodies Used for Immunohistochemical Study

\begin{tabular}{lcccc}
\hline Antibody Specificity & Clone & Dilution & Antigen Retrieval/Time (min) & Source \\
\hline S100 protein & Polyclonal & RTU & CC1/20 & Ventana \\
CK7 & OV-TL 12/30 & $1: 200$ & CC1/36 & Dako Cytomation \\
GCDFP-15 & EP1582y & RTU & CC1/64 Marque & Dako Cytomation \\
Mammaglobin & $304-1$ A5 & RTU & CC1/36 & Assay Designs Inc. \\
STAT 5a & Polyclonal & $1: 400$ & CC1/36 & Ventana \\
Ki-67 & $30-9$ & RTU & VC1/64 & Centana Marque \\
P63 & $4 A 4$ & RTU & CC1/36 & BioCare Medical \\
DOG1 & SP31 & RTU & CC1/52 & Cell Marque \\
GATA3 & L50-823 & $1: 200$ & CC1/64 & \\
SOX10 & Polyclonal & $1: 100$ & &
\end{tabular}

$\mathrm{CCl}$ indicates EDTA buffer, $\mathrm{pH}$ 8.6; RTU, ready to use (prediluted).

ETV6-NTRK3 fusion gene due to a $\mathrm{t}(12 ; 15)(\mathrm{p} 13, \mathrm{q} 25)$ translocation, a finding identical to $\mathrm{SC}$ of the breast ${ }^{2}$ and absent in AciCCs. ${ }^{1}$ Because of the morphologic similarities and identical ETV6-NTRK3 fusion transcripts, the designation "mammary analog secretory carcinoma of salivary gland" has been proposed, ${ }^{1}$ and the name was widely accepted and used in the literature. The most recent version of the World Health Organization Classification of Head and Neck Tumors, however, utilizes the terminology "secretory carcinoma" 4 for consistency, and because SCs have been recently described at other extrasalivary and extramammary sites, such as thyroid gland, ${ }^{5-8}$ skin,,${ }^{9,10}$ and sinonasal mucosa. ${ }^{11}$

The presence of the ETV6-NTRK3 fusion gene has not been demonstrated in any other salivary gland tumor, but the same translocation can be seen not only in SC of breast, ${ }^{2}$ but also in infantile fibrosarcoma, ${ }^{12}$ congenital mesoblastic nephroma, ${ }^{13}$ certain hematopoietic malignancies ${ }^{14}$ ALKnegative inflammatory myofibroblastic tumors, ${ }^{15}$ a small subset of gastrointestinal stromal tumors, ${ }^{16}$ and in radiation-induced papillary thyroid carcinomas. ${ }^{17}$ Moreover, ETV6-NTRK3 translocated papillary thyroid cancers have been recently described in adult patients with no history of radiation exposure. ${ }^{18}$

The near $100 \%$ rate of ETV6 gene rearrangement in SC has been subsequently confirmed by many other studies. ${ }^{19-25}$ Detection of ETV6 rearrangements by fluorescent in situ hybridization (FISH) or the ETV6-NTRK3 fusion by reversetranscriptase polymerase chain reaction (RT-PCR) in formalin-fixed paraffin-embedded (FFPE) material is technically relatively straightforward and $>300$ cases of SC have been published since its original description.

Up until now, in all published cases of SC where the fusion partner is identified, ETV6 is fused with NTRK3, and no other fusion partners have been reported so far. Nevertheless, for several years, we have been aware of several SC cases positive for the ETV6 gene split as visualized by FISH, but in which the classic ETV6-NTRK3 fusion transcript (exon 5-exon 15 junction) was not detected by standard RT-PCR. A subset of SCs showing ETV6 rearrangements with so far unknown partners have been recently reported and provisionally called ETV6-X translocated $\mathrm{SCs},{ }^{26}$ in agreement with a study of Ito et $\mathrm{al},{ }^{27}$ who found 2 such cases. In the present study using the next-generation sequencing (NGS) as a diagnostic platform, we describe 10 cases morphologically and immunohistochemically typical of SC, harboring a novel ETV6-RET translocation.

\section{MATERIALS AND METHODS}

Among $>4500$ cases of primary salivary gland tumors, 194 cases of SCs were retrieved from the consultation files of the Salivary Gland Tumor Registry, at

TABLE 2. Primers for Detection of ETV6-NTRK3 Fusion Transcripts

\begin{tabular}{lcrc}
\hline Original Primer Name & Sequence & Annealing Temperature $\left({ }^{\circ} \mathbf{C}\right)$ & Localization \\
\hline ETV6-ex4-F3 & AGCCGGAGGTCATACTGCAT & 55 & ETV6 exon 4 inner \\
ETV6-ex4-F4 & CATTCTTCCACCCTGGAAAC & ETV6 exon 4 outer \\
ETV6B $\dagger$ & ACATCATGGTCTCTGTCTCCCCGC & 55 & ETV6 exon 5 inner \\
TEL971* ETV6A $\dagger)$ & ACCACATCATGGTCTCTGTCTCCC & 55 & ETV6 exon 5 outer \\
NTRK3-ex14-R1 & GTGATGCCGTGGTTGATGT & NTRK3 exon 14 inner \\
NTRK3 ex14-R2 & AGTCATGCCAATGACCACAG & 55 & NTRK3 exon 14 outer \\
NTRK3B $\dagger$ & TTCTCGCTTCAGCACGATGTCT & 55 & NTRK3 exon 15 inner \\
TRKC1059* NTRK3A $\dagger)$ & CAGTTCTCGCTTCAGCACGATG & 55 & NTRK3 exon 15 outer \\
ETV6-Archer1-F1 & CGATGGGAGGACAAAGAATC & ETV6 exon 6 \\
RET-Archer1-R1 & AACCAAGTTCTTCCGAGGGA & 65 & RET exon 12 \\
ETV6-Archer1-F2 & CAACGGACTGGCTCGACTG & 55 & ETV6 exon 6 \\
RET-Archer1-R2 & GACCACTTTTCCAAATTCGCCT & 55 & RET exon 12 \\
\hline
\end{tabular}

*Bourgeois et a132

$\dagger$ Ito et $\mathrm{al}^{27}$ Skalova et $\mathrm{al}^{26}$ 
A
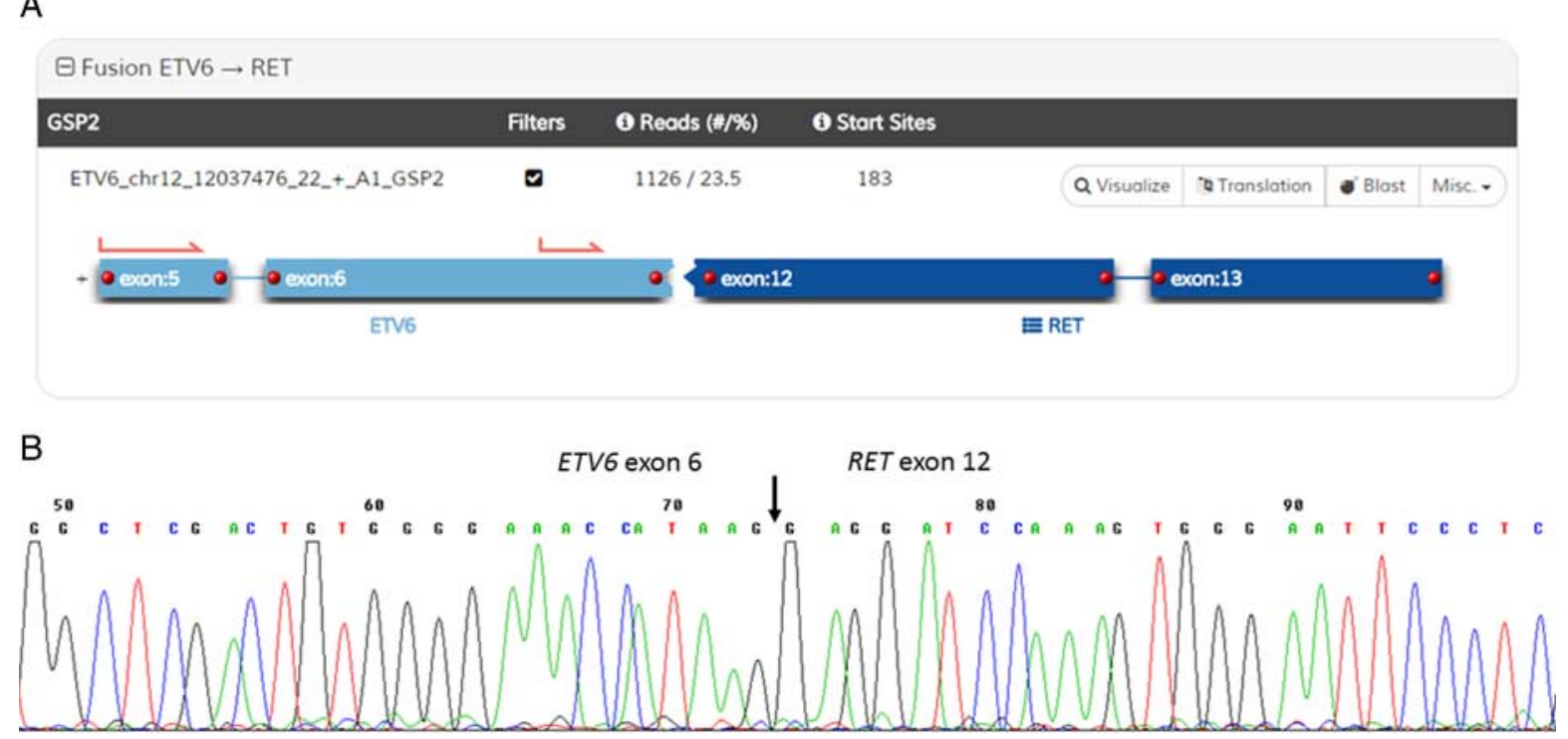

FIGURE 1. A, The result of analysis by NGS with custom-designed ArcherDX Kit of case 3 (case 17 in Skalova et al ${ }^{26}$ ). Analysis revealed the presence of fusion transcript ETV6-RET joining exons 6 and 12, respectively. The red arrows represent position of primers. B, The confirmation of the presence of ETV6-RET fusion transcript by RT-PCR followed by Sanger sequencing. The black arrow indicates area of fusion.

the Department of Pathology, Faculty of Medicine in Plzen, and Biopticka Laborator Ltd, Plzen, Czech Republic (A.S. and M.M.).

The histopathologic features of all tumors and the immunohistochemical stains, when available, were reviewed by 2 pathologists (A.S. and M.B.). A diagnosis of SC was confirmed in cases that displayed, at least focally, histologic features consistent with original description ${ }^{1}$ in conjunction with the appropriate immunohistochemical profile, that is, coexpression of S100 protein, cytokeratin CK7, and mammaglobin with the absence of p63 and DOG1 staining. For the purpose of this particular study, we have included 4 cases of SC with ETV6-X profile from study Skalova et $\mathrm{al}^{26}$ and 26 cases of SC with ETV6 gene break found by FISH or with morphologic and immunohistochemical pattern of SC but without analyzable ETV6 gene break by FISH due to low quality or lack of material. Thus, a total of $30 \mathrm{SC}$ cases were studied by NGS using ArcherDX Fusion Plex Kit.

For conventional microscopy, the excised tissues were fixed in formalin, routinely processed, embedded in paraffin (FFPE), cut, and stained with hematoxylin and eosin. In most cases, additional stains were also performed, including periodic acid-Schiff with and without diastase, mucicarmine, and alcian blue at $\mathrm{pH}$ 2.5.

For immunohistochemical studies, $4 \mu \mathrm{m}$ thick sections were cut from paraffin blocks and mounted on positively charged slides (TOMO, Matsunami Glass Ind., Japan). Sections were processed on a BenchMark ULTRA (Ventana Medical System, Tucson, AZ), deparaffinized, and then subjected to heat-induced epitope retrieval by immersion in a $\mathrm{CCl}$ solution at $\mathrm{pH} 8.6$ at $95^{\circ} \mathrm{C}$. After antigen retrieval, sections were stained with a panRTK antibody cocktail consisting of rabbit monoclonal antibodies, all obtained from Cell Signaling (Danvers, MA), targeting pan-Trk (A7H6R, active against TrkA, TrkB, and TrkC, 1:50 dilution), ROS1 (D4D6, 1:50), and ALK (D5F3, 1:50), as described previously. ${ }^{28}$

All other primary antibodies used are summarized in Table 1. The bound antibodies were visualized using the ultraView Universal DAB Detection Kit (Roche) and ultraView Universal Alkaline Phosphatase Red Detection Kit (Roche). The slides were counterstained with the Mayer hematoxylin. Appropriate positive and negative controls were used.

Clinical follow-up was obtained from the patients, their physicians, or from referring pathologists.

\section{Molecular Genetic Study}

\section{Detection of ETV6-NTRK3 and ETV6-RET Fusion Transcripts by RT-PCR}

RNA was extracted using the RecoverAll Total Nucleic Acid Isolation Kit (Ambion, Austin, TX). cDNA was synthesized using the Transcriptor First Strand cDNA Synthesis Kit (RNA input $500 \mathrm{ng}$; Roche Diagnostics, Mannheim, Germany). All procedures were performed according to the manufacturer's protocols. Amplification of a 105 and $133 \mathrm{bp}$ product of the $\mu 2$-microglobulin gene and $247 \mathrm{bp}$ product of the $P G K$ gene was used to test the quality of the extracted RNA as previously described. ${ }^{29-31}$ A detection of classic exon 5 of ETV6 gene and exon 15 of NTRK3 gene, ${ }^{32}$ as well as atypical exon 4 of the ETV6 gene and exon 14 of the NTRK3 gene (and their combinatorial variants) fusion transcript was performed by RT-PCR. In addition, more sensitive, nested RT-PCR was performed for the detection of classic ${ }^{26,27}$ as well as selected atypical junction of transcripts. Except that, 
A

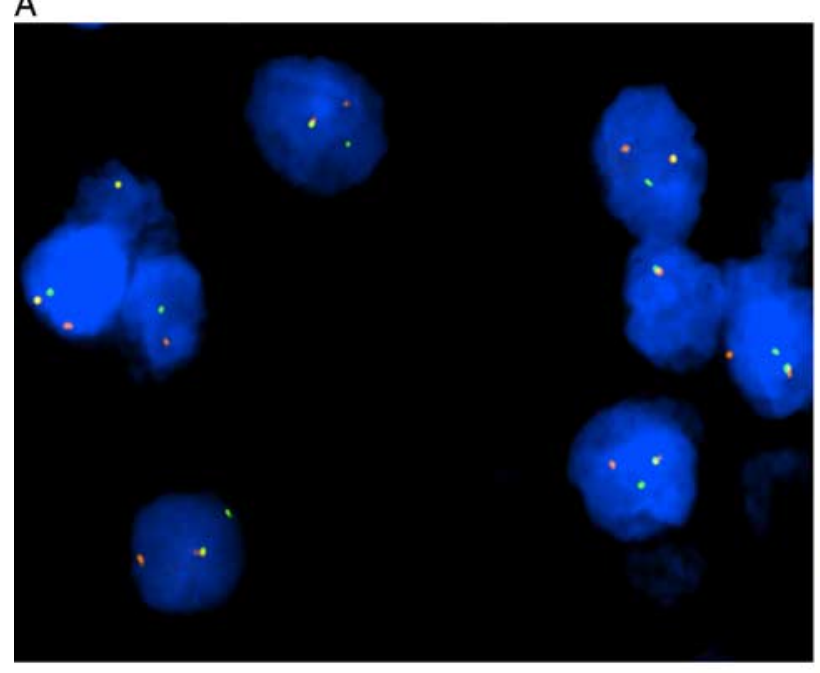

C

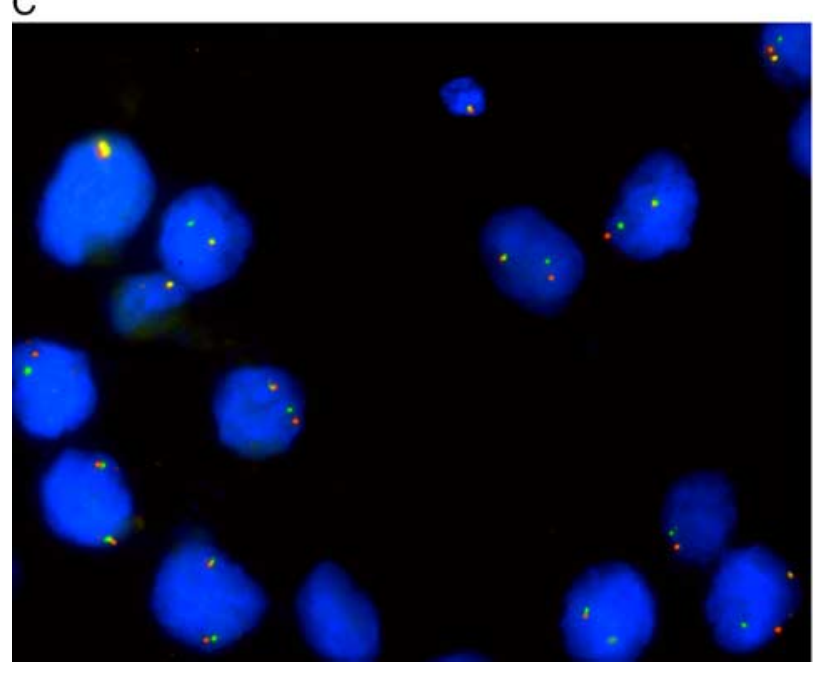

B

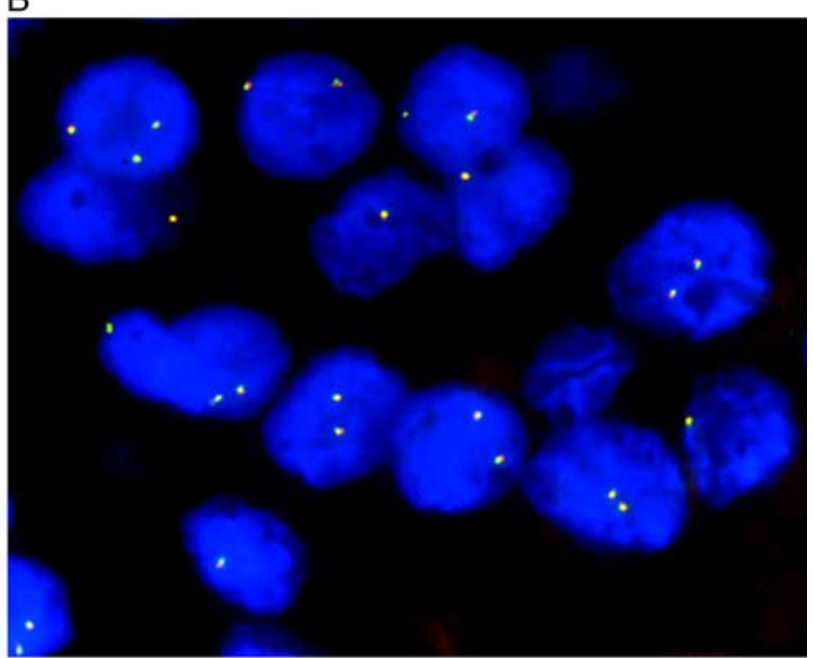

D

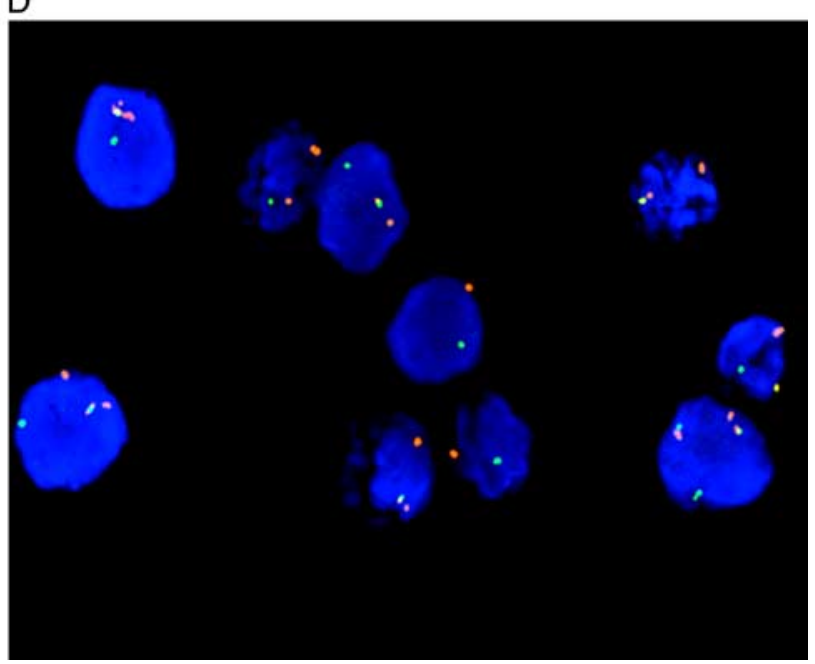

FIGURE 2. Interphase FISH analysis using break-apart probes (A-C) and dual-fusion probe (D). Positive cells with break-apart ETV6 (A) and RET (C) probes contain nucleus with separate (split) orange and (or) green signals indicating a rearrangement (break) of 1 copy of the gene region and also 1 orange/green (yellow) fusion signal representing 1 normal (intact) copy of homolog locus. Negative cells with break-apart NTRK3 (B) probe contain only normal (not split) yellow signal. Positive cells using fusion probe ETV6-RET (D) show orange/green (yellow) fusion signals representing translocation ETV6-RET and also separate orange and green signals showing the intact genes.

RT-PCR for ETV6-RET fusion transcript detection was also carried out after receiving of the NGS results.

For single-round PCR, $2 \mathrm{~L}$ of cDNA was added to reaction consisting of $12.5 \mu \mathrm{L}$ of HotStar Taq PCR Master Mix (QIAgen, Hilden, Germany), 10 pmol of each primer (Table 2), and distilled water up to $25 \mu \mathrm{L}$. The amplification program comprised denaturation at $95^{\circ} \mathrm{C}$ for 14 minutes and then 45 cycles of denaturation at $95^{\circ} \mathrm{C}$ for 1 minute, annealing at temperature seen in Table 2 for 1 minute and extension at $72^{\circ} \mathrm{C}$ for 1 minute. The program was finished by incubation at $72^{\circ} \mathrm{C}$ for 7 minutes. For nested PCR, the same reaction conditions were utilized. One microliter of PCR product from the first round was used as a template.

Successfully amplified PCR products were purified with magnetic particles of Agencourt AMPure (Agencourt
Bioscience Corporation, A Beckman Coulter Company, Beverly, MA). Products were then bidirectionally sequenced using Big Dye Terminator Sequencing Kit (Applied Biosystems, Foster City, CA), and purified with magnetic particles of Agencourt CleanSEQ (Agencourt Bioscience Corporation), all according to the manufacturer's protocol, and run on an automated sequencer ABI Prism 3130xl (Applied Biosystems) at a constant voltage of $13.2 \mathrm{kV}$ for 11 minutes.

\section{Detection of Alteration of ETV6, NTRK3, and RET Genes by FISH Method}

Four-micrometer-thick FFPE sections were placed onto positively charged slides. Hematoxylin and eosinstained slides were examined for determination of areas for cell counting. 
TABLE 3. Molecular Genetics Findings in 10 Cases of SC With ETV6-RET Fusion

\begin{tabular}{|c|c|c|c|c|c|c|c|c|c|}
\hline Case \# & Case \# & $\begin{array}{c}\text { NGS } \\
\text { Results }\end{array}$ & Fusion & $\begin{array}{c}\text { FISH } \\
\text { ETV6ba }\end{array}$ & $\begin{array}{c}\text { FISH } \\
\text { NTRK3ba }\end{array}$ & $\begin{array}{c}\text { RT-PCR } \\
\text { ETV6-NTRK3 } \\
\end{array}$ & $\begin{array}{c}\text { FISH } \\
\text { RETba } \\
\end{array}$ & $\begin{array}{c}\text { FISH } \\
\text { ETV6-RET } \\
\end{array}$ & $\begin{array}{c}\text { RT-PCR } \\
\text { ETV6-RET }\end{array}$ \\
\hline 1 & $6^{*}$ & + & ETV6-RET & + & - & - & + & + & + \\
\hline 2 & $15^{*}$ & + & ETV6-RET & + & - & - & + & ND & + \\
\hline 4 & $20^{*}$ & + & ETV6-RET & + & - & - & + & + & - \\
\hline 5 & & + & ETV6-RET & + & - & - & + & + & + \\
\hline 6 & & + & ETV6-RET & ND & ND & - & ND & + & + \\
\hline 10 & $12 \dagger$ & + & ETV6-RET & + & - & - & + & + & + \\
\hline
\end{tabular}

*Skalova et $\mathrm{al}^{26}$ (Table 6).

$\dagger$ Stevens et al ${ }^{8}$ (Table 2).

NA indicates not analyzable; ND, not done due to lack of material.

The unstained slides were routinely deparaffinized and incubated in the $\times 1$ Target Retrieval Solution Citrate pH 6 (Dako, Glostrup, Denmark) at $95^{\circ} \mathrm{C}$ for 40 minutes and subsequently cooled for 20 minutes at room temperature in the same solution. Slides were washed in deionized water for 5 minutes and digested in protease solution with Pepsin $(0.5 \mathrm{mg} / \mathrm{mL}$; Sigma Aldrich, St Louis, $\mathrm{MO})$ in $0.01 \mathrm{M} \mathrm{HCl}$ at $37^{\circ} \mathrm{C}$ for 25 to 60 minutes, according to the sample conditions. Slides were then placed into deionized water for 5 minutes, dehydrated in a series of ethanol solutions $(70 \%, 85 \%, 96 \%$ for $2 \mathrm{~min}$ each), and air dried.

Two commercial probes were used for the detection of rearrangement of ETV6 and RET genes, Vysis ETV6 Break Apart FISH Probe Kit (Vysis/Abbott Molecular, IL) and ZytoLight SPEC RET Dual Color Break Apart Probe (ZytoVision GmbH, Bremerhaven, Germany). ETV6 probe was mixed with water and LSI/WCP (LocusSpecific Identifier/Whole Chromosome Painting) Hybridization buffer (Vysis/Abbott Molecular) in a 1:2:7 ratio, respectively. RET probe was factory premixed.

Probes for detection of rearrangement of $N T R K 3$ gene region and ETV6-RET genes fusion were mixed from custom designed SureFISH probes (Agilent Technologies Inc., Santa Clara, CA). Chromosomal regions for NTRK3 break-apart probe oligos are chr15:87501469-88501628 and chr15:88701444-89700343; for ETV6-RET fusion probe, chr12:11675872-12175711 and chr10:43354893-43849282. Probe mixture was prepared from corresponding probes (each color was delivered in a separate well), deionized water, and LSI Buffer (Vysis/Abbott Molecular) in a 1:1:1:7 ratio, respectively.

An appropriate amount of mixed and premixed probes was applied on specimens, covered with a glass coverslip, and sealed with rubber cement. Slides were incubated in the ThermoBrite instrument (StatSpin/Iris Sample Processing, Westwood, MA) with codenaturation at $85^{\circ} \mathrm{C}$ for minutes and hybridization at $37^{\circ} \mathrm{C}$ for hours. Rubber cemented coverslip was then removed and the slide was placed in posthybridization wash solution $(2 \times \mathrm{SSC} / 0.3 \% \mathrm{NP}-40)$ at $72^{\circ} \mathrm{C}$ for 2 minutes. The slide was air dried in the dark, counterstained with $4^{\prime}, 6^{\prime}$-diamidino2-phenylindole DAPI (Vysis/Abbott Molecular), coverslipped, and immediately examined.

\section{FISH Interpretation}

The sections were examined with an Olympus BX51 fluorescence microscope (Olympus Corporation, Tokyo, Japan) using a $\times 100$ objective and filter sets Triple Band Pass (DAPI/SpectrumGreen/SpectrumOrange), Dual Band Pass (SpectrumGreen/SpectrumOrange), and Single Band Pass (SpectrumGreen or SpectrumOrange).

TABLE 4. Details of NGS Analysis by the Archer Platform in 10 Cases of SC With ETV6-RET Translocation

\begin{tabular}{|c|c|c|c|c|c|c|c|}
\hline Case \# & Case \# & $\begin{array}{c}\text { NGS } \\
\text { Results }\end{array}$ & Fusion & $\begin{array}{c}\text { Exons Included in } \\
\text { Fusion }\end{array}$ & $\begin{array}{c}\text { No. Valid Fusion } \\
\text { Read }\end{array}$ & $\begin{array}{c}\% \text { of Reads Supporting } \\
\text { Fusion }\end{array}$ & $\begin{array}{c}\text { No. Unique Start } \\
\text { Sites }\end{array}$ \\
\hline 1 & Case $6^{*}$ & + & ETV6-RET & $6-12$ & 51 & 100 & 17 \\
\hline 2 & Case $15^{*}$ & + & ETV6-RET & $6-12$ & 84 & 20.1 & 33 \\
\hline 4 & Case $20^{*}$ & + & ETV6-RET & $6-12$ & 15 & 1.8 & 10 \\
\hline 5 & & + & ETV6-RET & $6-12$ & 163 & 11.4 & 63 \\
\hline 6 & & + & ETV6-RET & $6-12$ & 21 & 100 & 11 \\
\hline 10 & Case $12 \dagger$ & + & ETV6-RET & $6-12$ & 24 & 14.8 & 17 \\
\hline
\end{tabular}




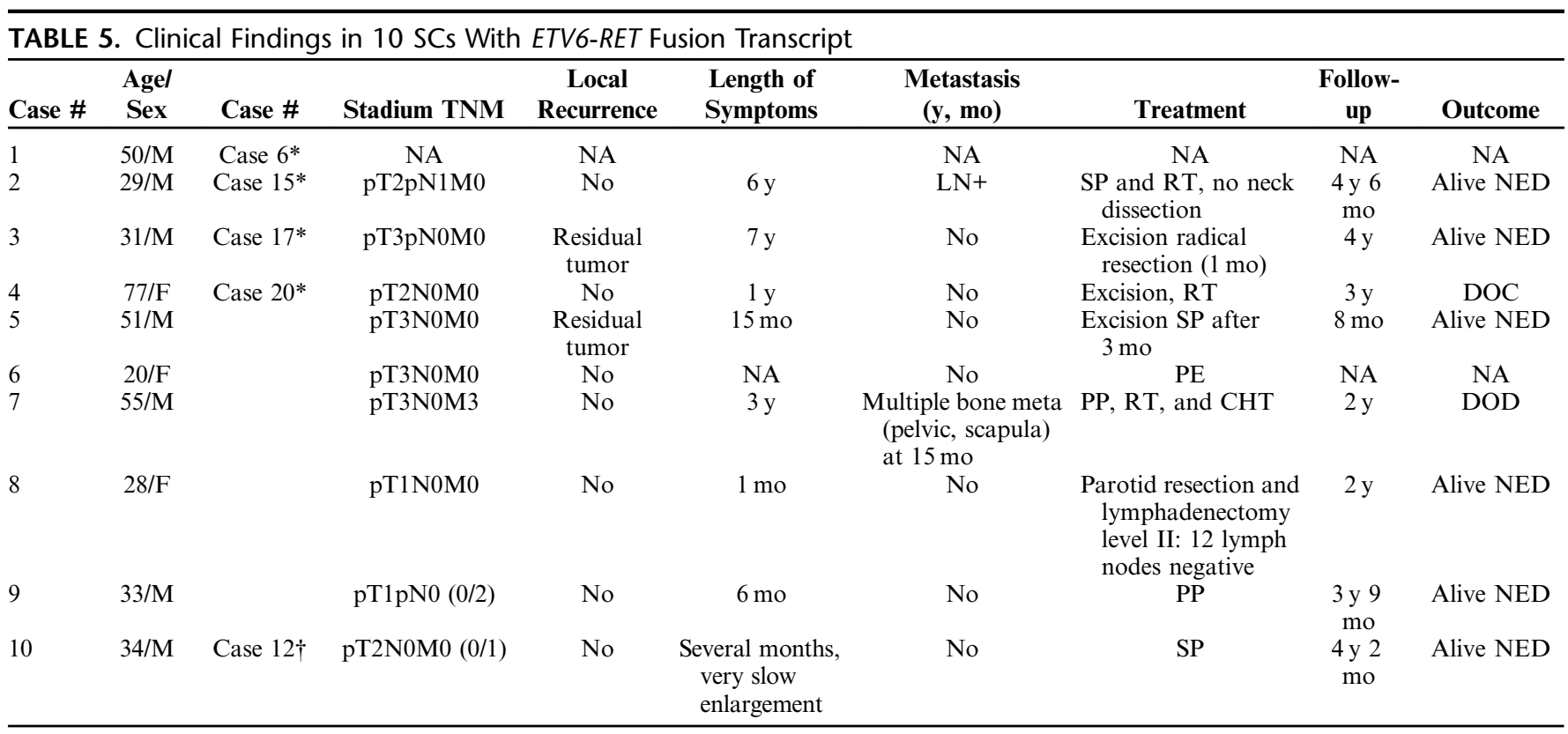

*Skalova et $\mathrm{al}^{26}$ (Table 6)

$\dagger$ Stevens et $\mathrm{al}^{8}$ (Table 2).

CHT indicates chemotherapy; DOC, dead of other causes; DOD, dead of disease; LN, lymph nodes; NA, not available; NED, no evidence of disease; PE, parotidectomy; PP, partial parotidectomy; RT, radiotherapy; SP, superficial parotidectomy.

For each probe, 100 randomly selected nonoverlapping tumor cell nuclei were examined for the presence of yellow or green and orange fluorescent signals. Regarding break-apart probes, yellow signals were considered negative, and separate orange and green signals were considered positive; conversely, for fusion probe, yellow signals were considered positive, and separate orange and green signals were considered negative.

Cutoff values were set to $>10 \%$ and $20 \%$ of nuclei (break-apart and fusion probes, respectively) with chromosomal breakpoint signals (mean, +3 SD rounded up in normal non-neoplastic control tissues).

\section{Sample Preparation for NGS}

For NGS studies, 2 to 3 FFPE sections ( $10 \mu \mathrm{m}$ thick) were macrodissected to isolate tumor-rich regions. Samples were extracted for total nucleic acid using Agencourt FormaPure Kit (Beckman Coulter, Brea, CA) following the corresponding protocol with an overnight digest and an additional $80^{\circ} \mathrm{C}$ incubation as described in modification of the protocol by ArcherDX (ArcherDX Inc., Boulder, CO). Total nucleic acid was quantified using the Qubit Broad Range RNA Assay Kit (Thermo Fisher Scientific) and $2 \mu \mathrm{L}$ of sample.

\section{RNA Integrity Assessment and Library Preparation for NGS}

Unless otherwise indicated, $250 \mathrm{ng}$ of FFPE RNA was used as input for NGS studies. To assess RNA quality, the PreSeq RNA QC Assay using iTaq Universal SYBR Green Supermix (Biorad, Hercules, CA) was performed on all samples during library preparation to generate a measure of the integrity of RNA (in the form of a cycle threshold value). Library preparation and RNA QC were performed following the Archer Fusion Plex Protocol for Illumina (ArcherDX Inc.). A custom primer set with 28 primers spanning regions on 3 specific genes of interest, including all 8 exons of ETV6 gene in $3^{\prime}$ direction, was designed and used. Final libraries were diluted 1:100,000 and quantified in a $10 \mu \mathrm{L}$ reaction following the Library Quantification for Illumina Libraries protocol and assuming a $200 \mathrm{bp}$ fragment length (KAPA, Wilmington, MA). The concentration of final libraries was around $200 \mathrm{nM}$. The threshold representing the minimum molar concentration for which sequencing can be robustly performed was set at $50 \mathrm{nM}$.

\section{NGS and Analysis}

Libraries were sequenced on a MiSeq sequencer (Illumina, San Diego, CA). They were diluted to $4 \mathrm{nM}$ and equal amounts of up to 16 libraries were pooled per run. The optimal number of raw reads per sample was set to 500,000 . Library pools were diluted to $16 \mathrm{pM}$ library stock with 5\% $12.5 \mathrm{pM}$ PhiX and loaded into the MiSeq cartridge. Analysis of sequencing results was performed using the Archer Analysis software (v5; ArcherDX Inc.). Fusion parameters were set to a minimum of 5 valid fusion reads with a minimum of 3 unique start sites within the valid fusion reads.

\section{RESULTS}

\section{Molecular Genetic Findings}

Selected 30 cases of SC (as described earlier) were analyzed by NGS using the ArcherDX analysis platform. 


\begin{tabular}{|c|c|c|c|c|c|c|c|c|c|c|c|c|}
\hline $\begin{array}{l}\text { Case } \\
\# \\
\end{array}$ & $\begin{array}{l}\text { Agel } \\
\text { Sex } \\
\end{array}$ & $\begin{array}{c}\text { Case } \\
\# \\
\end{array}$ & Location & $\begin{array}{c}\text { Tumor } \\
\text { Size } \\
(\mathrm{mm}) \\
\end{array}$ & Capsule & $\begin{array}{l}\text { Surgical } \\
\text { Margins } \\
\end{array}$ & $\begin{array}{c}\text { Thick } \\
\text { Fibrous } \\
\text { Septa } \\
\end{array}$ & $\begin{array}{c}\text { Hyalinized } \\
\text { Sclerosis }\end{array}$ & $\begin{array}{c}\text { Invasion } \\
\text { (LVI, PN) }\end{array}$ & $\begin{array}{c}\text { Cystic } \\
\text { Pattern } \\
\end{array}$ & Necrosis & Comments \\
\hline 1 & $50 / \mathrm{M}$ & $\begin{array}{c}\text { Case } \\
6^{*}\end{array}$ & Lip & 15 & NA & 2 & No & No & NA & No & - & $\begin{array}{l}\text { Fragmented } \\
\text { tissue }\end{array}$ \\
\hline 2 & $29 / \mathrm{M}$ & $\begin{array}{l}\text { Case } \\
15^{*}\end{array}$ & Parotid & 23 & No & 1 & + & ++ & $\begin{array}{c}\mathrm{PN}+, \mathrm{LVI} \\
+ \text { Extraglandular, } \\
\text { muscle invasion }\end{array}$ & No & - & $\begin{array}{l}\text { Hyalinized, } \\
\text { multilobular, } \\
\text { microcystic, } \\
\text { and solid } \\
\text { growth pattern }\end{array}$ \\
\hline 3 & 31/M & $\begin{array}{l}\text { Case } \\
17^{*}\end{array}$ & Submand & 30 & No & 2 & ++ & ++ & $\mathrm{PN}+$ & No & - & $\begin{array}{l}\text { Hyalinized, } \\
\text { multilobular, } \\
\text { microcystic }\end{array}$ \\
\hline 4 & $77 / \mathrm{F}$ & $\begin{array}{l}\text { Case } \\
20^{*}\end{array}$ & Submand & 70 & Focal & & + & + & No & + & - & $\begin{array}{l}\text { Multicystic, } \\
\text { papillary with } \\
\text { apocrine cells }\end{array}$ \\
\hline 6 & $20 / \mathrm{F}$ & & Parotid & 40 & No & 2 & + & + & Extraglandular & No & - & $\begin{array}{l}\text { Lobular, } \\
\text { microcystic }\end{array}$ \\
\hline 7 & $55 / \mathrm{M}$ & & Parotid & 70 & No & 2 & + & + & $\begin{array}{l}\mathrm{PN}+, \\
\text { perivascular }\end{array}$ & + & + & $\begin{array}{l}\text { High grade } \\
\text { component }\end{array}$ \\
\hline 8 & $28 / \mathrm{F}$ & & Parotid & 12 & No & 1 & + & + & Intraglandular & No & - & $\begin{array}{l}\text { Predominantly } \\
\text { solid and } \\
\text { microcystic }\end{array}$ \\
\hline 9 & $33 / \mathrm{M}$ & & Parotid & 17 & + & 1 & No & No & No & + & - & $\begin{array}{l}\text { Predominantly } \\
\text { cystic }\end{array}$ \\
\hline 10 & $34 / \mathrm{M}$ & $\begin{array}{l}\text { Case } \\
12 \dagger\end{array}$ & Parotid & 19 & + & 0 & No & No & No & + & - & $\begin{array}{l}\text { Multicystic with } \\
\text { mural nodules }\end{array}$ \\
\hline
\end{tabular}

*Skalova et $\mathrm{al}^{26}$ (Table 6).

†Stevens et $\mathrm{al}^{8}$ (Table 2).

Surgical margins: free-0; close (means distance from the tumor $<0.5 \mathrm{~mm}$ ) -1 ; positive-2.

F indicates female; LVI, lymphovascular invasion; M, male; NA, not available; PN, perineural invasion.

This analysis detected a novel ETV6-RET fusion transcript joining exon 6 of ETV6 gene and exon 12 of RET gene in 10 cases of salivary gland tumors displaying histologic and immunohistochemical features typical of SC (Fig. 1). All but 1 ETV6-RET positive SC case were then tested by at least 1 FISH probe for the presence of ETV6-RET rearrangements (Fig. 2). In case 9, there was no residual tissue material for confirmation of the NGS analysis by FISH tests. In addition, RT-PCR for the confirmation of the presence of ETV6-RET fusion transcript followed by Sanger sequencing on positive samples was performed in all 10 cases (Fig. 1). The results of the NGS tests, details of the analysis, and results of confirmatory genetic tests are summarized in Tables 3 and 4. In addition, NGS analysis resulted in detection of the ETV6-NTRK3 fusion in $15 \mathrm{SC}$ cases. In 4 cases, NGS revealed negative results, and 1 case was unanalyzable (detailed data not shown). No other fusion transcripts different from ETV6-NTRK3 or ETV6-RET were found by NGS in any analyzable case of SC.

\section{Clinical and Histologic Characteristics of the Study Group}

The clinical and follow-up data of 10 patients with ETV6-RET translocated SC of salivary glands are summarized in Table 5. There were 3 female and 7 male patients. The median patient age was 40.8 years, with a range between 20 and 77 years. The most common anatomic site of involvement was the parotid gland, occurring in 7 patients. Other primary sites of the origin included the submandibular gland and minor salivary gland of the upper lip in 2 patients and 1 patient, respectively.

\section{Follow-up Data}

Clinical follow-up data were obtained from 8 patients, and ranged from 6 to 50 months (mean, $36 \mathrm{mo}$ ); 2 patients were lost to follow-up. Detailed clinical, follow-up, and histologic findings in 10 patients with ETV6-RET translocated SC are summarized in Table 5.

All tumors were treated by surgical excision; in 1 patient the excision was radical with clear surgical margins, in 4 cases the surgical margins were positive, and in 4 additional patients, the tumor infiltration was close $(<0.5 \mathrm{~mm})$ to the surgical margins. Five patients underwent subtotal conservative parotidectomy, in 3 of them in combination with radiotherapy (cases 2, 4, and 7). Residual tumors were treated by radical reexcision with clear surgical margins in 2 patients. Concomitant chemotherapy and radiotherapy was used in 1 patient with high-grade transformed SC complicated by metastatic 
A
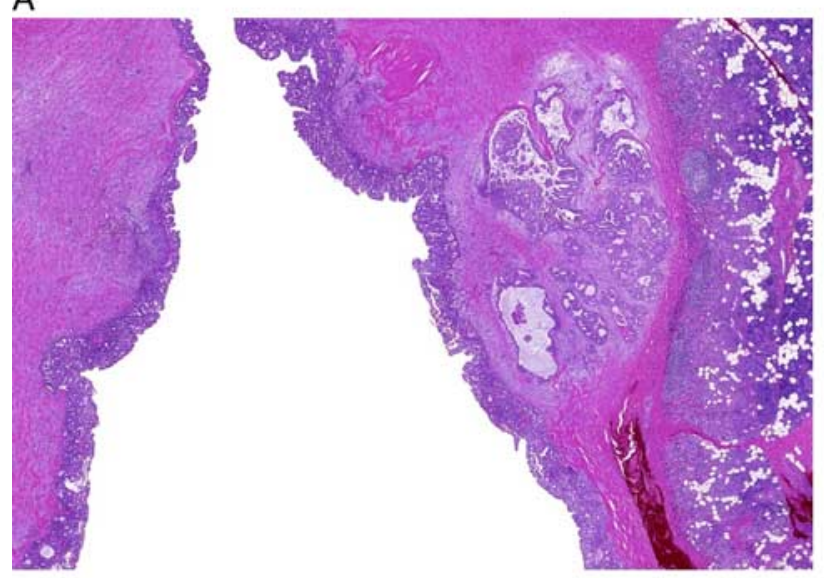

C

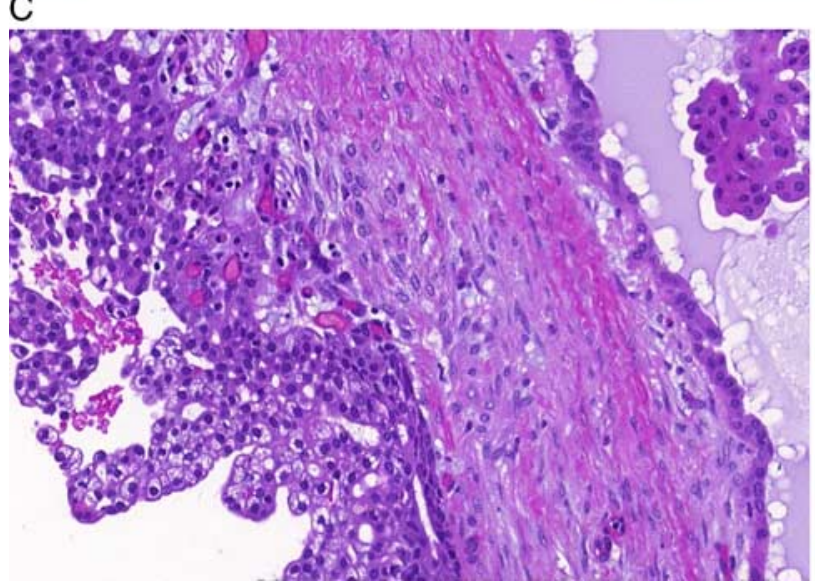

B

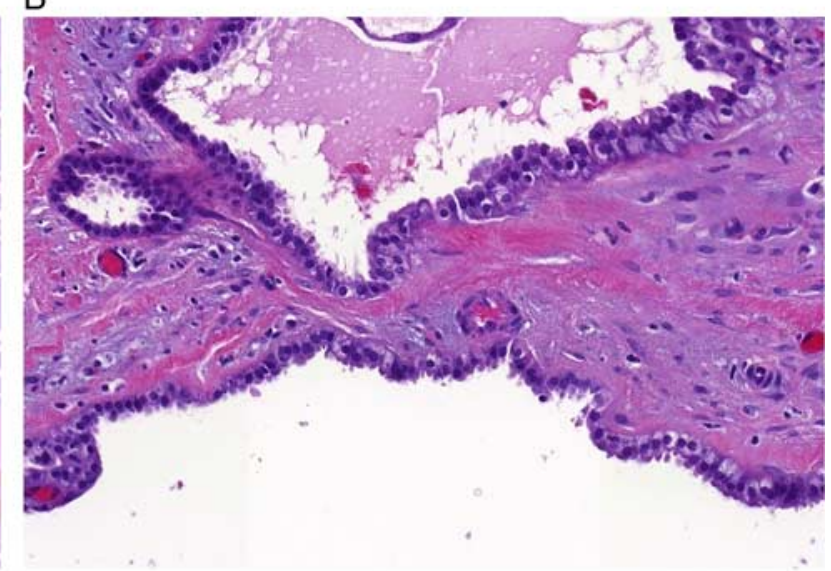

\section{.}

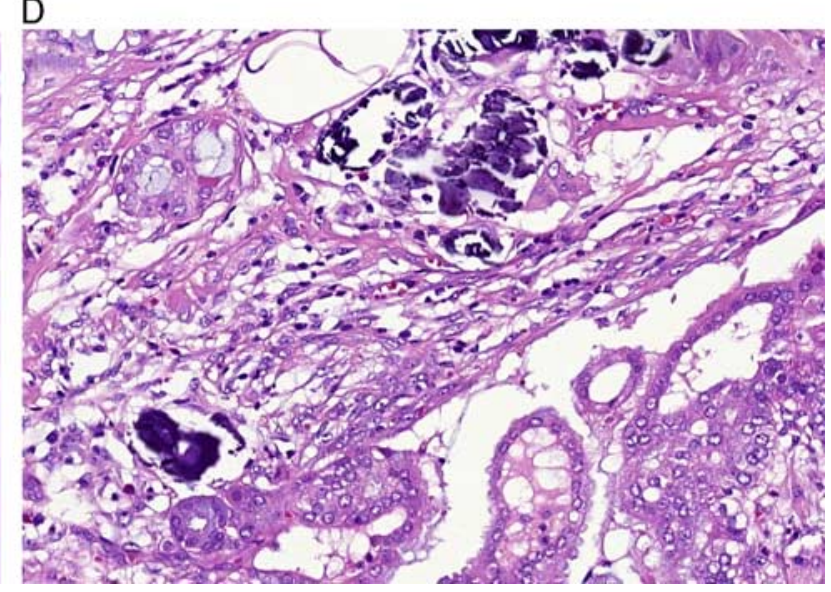

FIGURE 3. A, SC is well circumscribed and surrounded by a thick fibrous capsule enclosing predominantly multicystic growth pattern with multiple mural nodules. The cysts were lined mostly by a single or focally by a double layer of cells with prominent apocrine differentiation including hobnail (B) and vacuolated foamy cells (C). The fibrous capsule and septa comprised psammoma bodies in places (D).

disease at 15 months after surgery (case 7). Clinical and follow-up findings are summarized in Table 5.

\section{Macroscopic Features}

Detailed clinical and morphologic findings in 10 patients with ETV6-RET translocated SC are summarized in Table 6. The median tumor size was $3.6 \mathrm{~cm}$, with a range of 1.0 to $7.0 \mathrm{~cm}$. Grossly, most tumors were variably invasive: 2 were entirely circumscribed and encapsulated, 1 had focally infiltrative edges, and 7 were predominantly infiltrative.

\section{Microscopic and Immunohistochemical Features}

On low power magnification, 3 major growth patterns of SC were identified in our material. First, 3 tumors were well circumscribed and surrounded by a thick, focally uninterrupted, fibrous capsule enclosing a predominantly multicystic growth pattern with multiple mural nodules (Fig. 3A). The cysts were lined mostly by a single or focally by a double layer of cells with prominent apocrine differentiation including hobnail and vacuolated foamy cells (Figs. 3B, C), and contained abundant proteinaceous eosinophilic material. The fibrous capsule and septa comprised psammomatoid calcifications in some places (Fig. 3D). The second pattern was characterized by solid and microcystic growth with a multilobular structure divided by thin fibrous septa (Fig. 4A). The tumors either lacked a capsule or were only partially encapsulated with prominent infiltrative borders (Fig. 4B). These cases were predominantly composed of microcystic and slightly dilated glandular spaces filled with a variable amount of eosinophilic homogenous secretory material (Fig. 4C). The third pattern, prevailing in 3 cases, comprised a prominent fibrosclerotic stroma with isolated tumor cells in small islands or trabeculae, which were seen in the central part of the tumor (Fig. 5A). In case 7, 2 different growth patterns were seen, in particular low-grade components arranged in multiple macrocystic and microcystic lobules with comedo-like necroses, and highgrade components with limited secretory material and high proliferative activity (Fig. 5B).

However, most tumors demonstrated 2 or more architectural patterns, with microcystic, tubular, solid, and papillary patterns often occurring together. Regardless of 
A

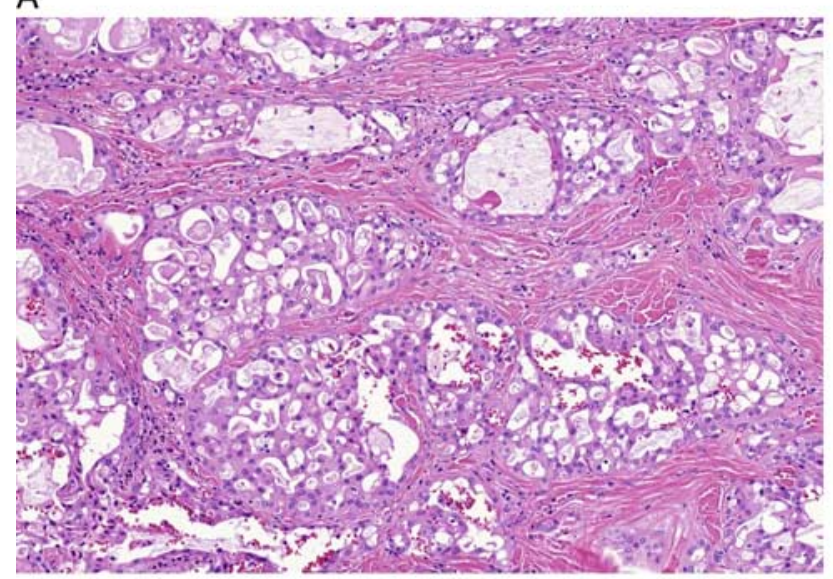

B
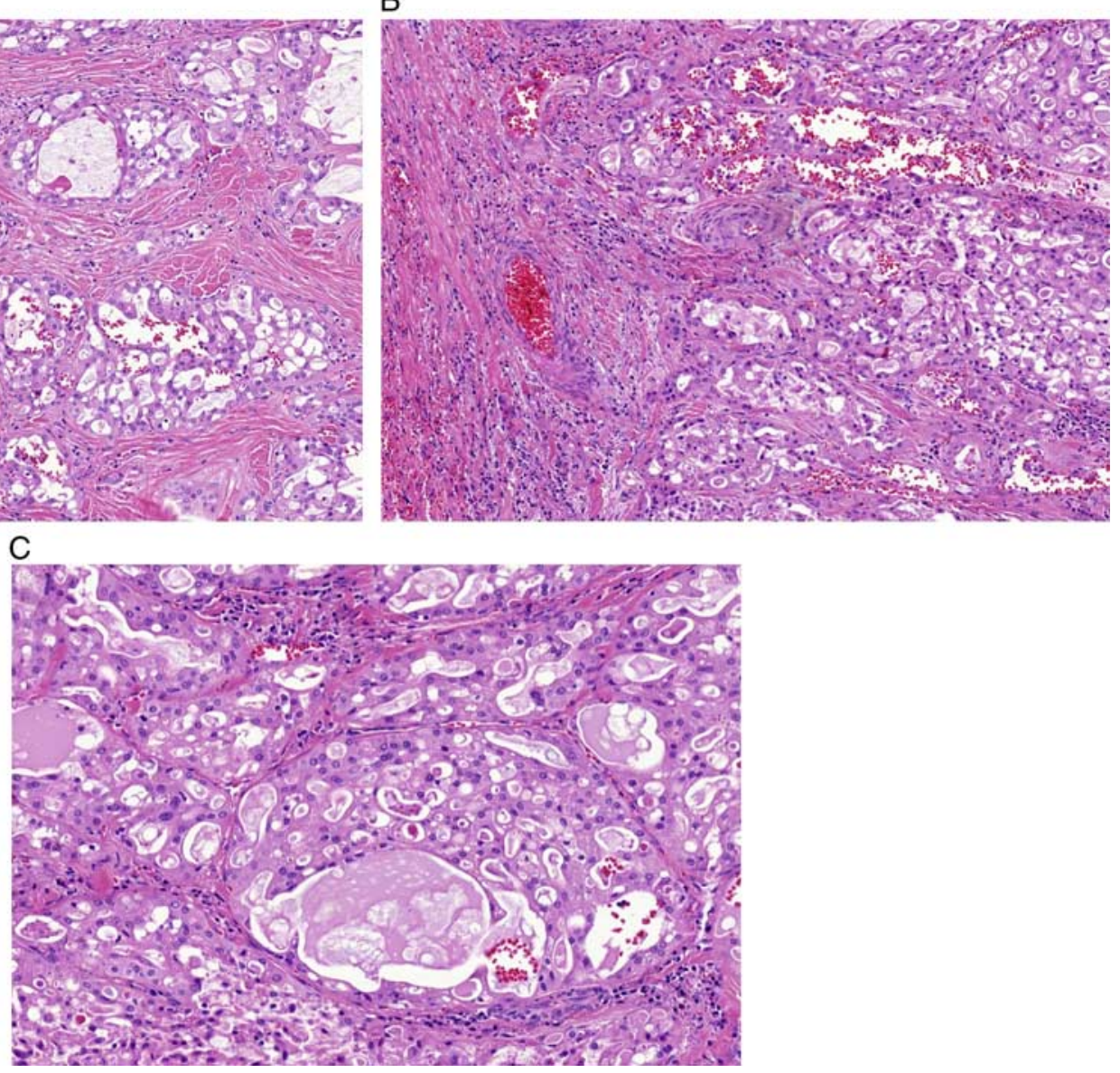

FIGURE 4. A, SC is characterized by solid and microcystic growth with a multilobular structure divided by thin fibrous septa. B, The tumor has a prominent infiltrative border. C, The tumor is predominantly composed of microcystic and slightly dilated glandular spaces filled with a variable amount of eosinophilic homogenous secretory material.

the growth pattern of SC, the tumor cells were often bland looking, with abundant pale pink vacuolated and foamy cytoplasm and with vesicular oval nuclei with a single small but prominent nucleolus. The cytologic features were similar from case to case. The range of nuclear atypia was assessed as grades 1 to 3. Mitotic figures were rare and necrosis was absent. Prominent perineural and intraneural invasion was seen in case 7 (Fig. 5C). Only 1 patient (case 2) presented with a single periparotideal lymph node metastasis at the time of diagnosis.

\section{Immunohistochemical Findings}

By immunohistochemistry, all examined SC cases were positive for S100 protein (Fig. 6A), mammaglobin (Fig. 6B), typically in strong and diffuse fashion (secretory material was also positive), and cytokeratin CK7 (Fig. 6C). GATA-3, SOX-10 (Fig. 6D), and STAT5a expression was detected in $3 / 6,5 / 6$, and $2 / 3$ cases, respectively. P63 protein was completely negative in most cases, with limited areas of positive peripheral myoepithelial cell staining suggestive of a focal intraductal component in 3 cases. DOG1 was negative in all examined cases.
Proliferative activity was generally low, with a mean MIB1 index of $15 \%$ (range, $5 \%$ to $40 \%$ ).

\section{DISCUSSION}

Salivary gland tumors are increasingly being found to have characteristic chromosomal rearrangements. SC is a salivary gland tumor that recapitulates the histology and genetics of a rare malignancy of the breast SC. These tumors are defined by the $\mathrm{t}(12 ; 15)(\mathrm{q} 13 ; \mathrm{q} 15)$ translocation, a fusion of the ETV6 gene from chromosome 12 and the NTRK3 gene from chromosome 15. The same translocation has been detected in most cases of the infantile fibrosarcomas, congenital mesoblastic nephromas, ${ }^{13}$ chronic eosinophilic leukemias, ${ }^{33}$ acute myeloid leukemia, ${ }^{14}$ and some papillary carcinomas of the thyroid with and without previous irradiation. ${ }^{18}$ These groups of tumors are the focus of interest, because tumors with ETV6-NTRK3 fusion translocation respond well to treatment by entrectinib, which is a potent inhibitor of tyrosine kinases TRKA/B/C, ROS1, and ALK. The drug entrectinib is administered orally, is safe and well tolerated, and can cross the blood-brain barrier, 

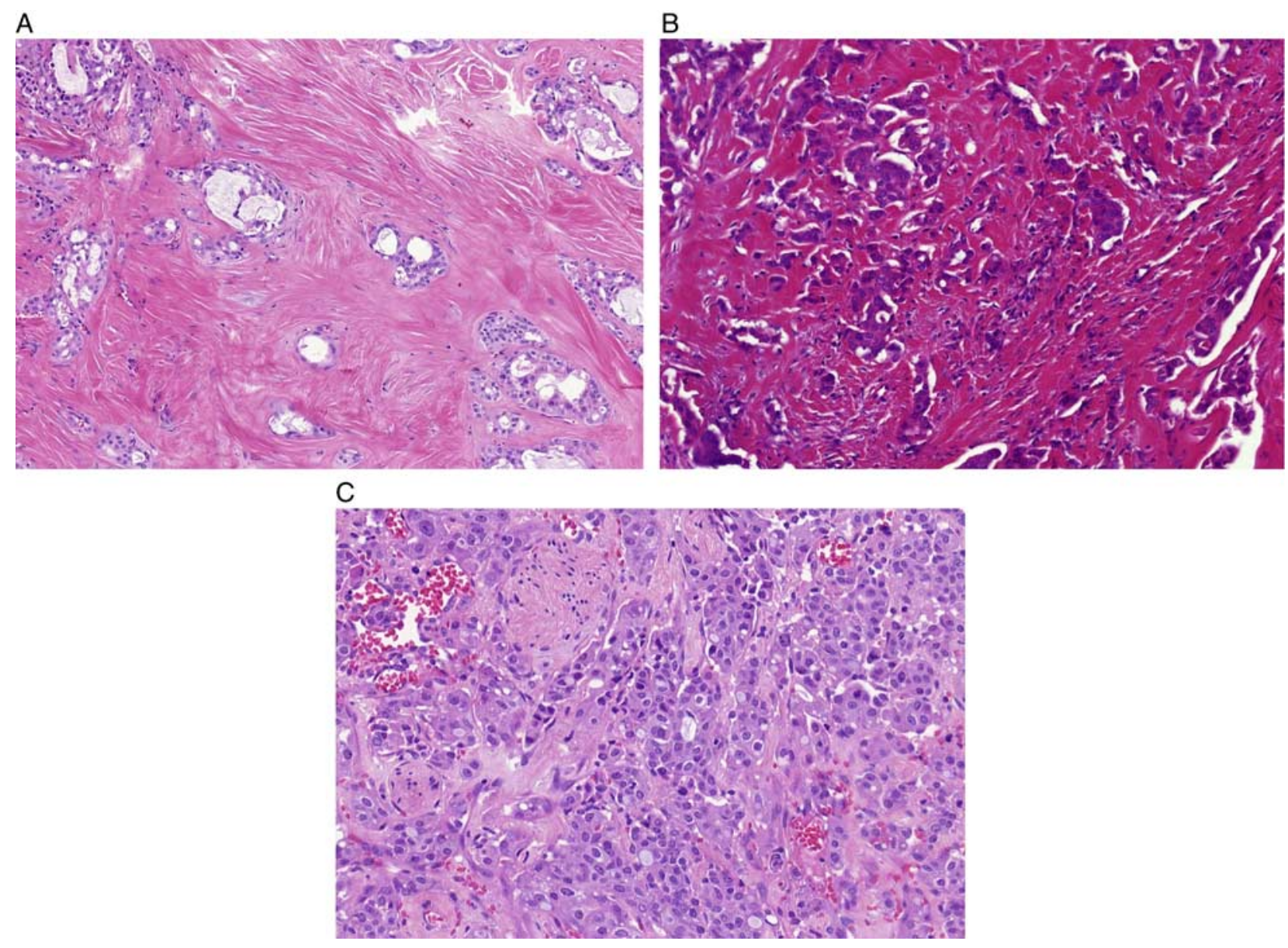

FIGURE 5. A, The third pattern of SC has a prominent fibrosclerotic stroma with isolated tumor cells in small islands or trabeculae were seen in the central part of the tumor. B, High-grade component of SC with limited secretory material and high proliferative activity. C, Prominent perineural and intraneural invasion was seen in 1 tumor.

so that it can be effective for treatment of brain metastases. ${ }^{34,35}$

Originally it appeared that all cases of SC share the same ETV6-NTRK3 fusion translocation. However, in recent years Ito et $\mathrm{al}^{27}$ and Skalova et $\mathrm{a}^{26}$ described altogether 6 cases of SC with the ETV6 gene split detected by FISH, but in which the ETV6 gene appeared to be fused with a gene different to NTRK3. These cases were marked as SCs with ETV6- $X$ fusion.

Herein, we describe a novel ETV6-RET fusion in 10 cases of salivary gland carcinomas with histologic features and IHC profile typical of SC, including the $4 E T V 6-X$ SC cases published previously. ${ }^{26}$ The presence of ETV6-RET fusion in SC was proven by at least 3 independent tests (NGS, FISH, RT-PCR), in all but 2 cases (Table 3, cases 4 and 9). In case 4, NGS and FISH confirmed ETV6-RET fusion but RT-PCR was negative, probably due to low or focal expression of fusion transcript (Table 4). Case 9 was the only sample unconfirmed by independent analysis. There was a lack of material for FISH analysis and RT-PCR for ETV6-RET fusion transcript detection was negative. In this case, low quality of RNA rather than low or focal expression is responsible for this result.

The alternative ETV6-RET transcription will be important for treatment of those SCs with uncontrolled regional growth or SCs with metastatic foci, as treatment with entrectinib and similar drugs with the same target specificity will probably be ineffective in these SCs with alternative fusion transcript different from ETV6-NTRK3. The alternative fusion partner different from ETV6-NTRK3 in SC should not be of great surprise, because infantile fibrosarcoma with ETV6-NTRK3 translocation may have alternative EML4-NTRK3 translocation, ${ }^{36}$ and there are descriptions of acute myeloid leukemias in which the ETV6 gene fuses with many alternative fusion partners, including ETV6-ABL1 ${ }^{37}$ ETV6-LPXN,${ }^{38}$ ETV6-RUNX1, ${ }^{39}$ ETV6-NCOA2, ${ }^{40}$ and many others.

To our knowledge, ETV6-RET fusions have not been reported in salivary gland tumors so far. Notably, however, recent studies using RNA sequencing have revealed that salivary duct carcinoma (SDC) may also be added to the growing list of gene fusion-positive salivary 
A
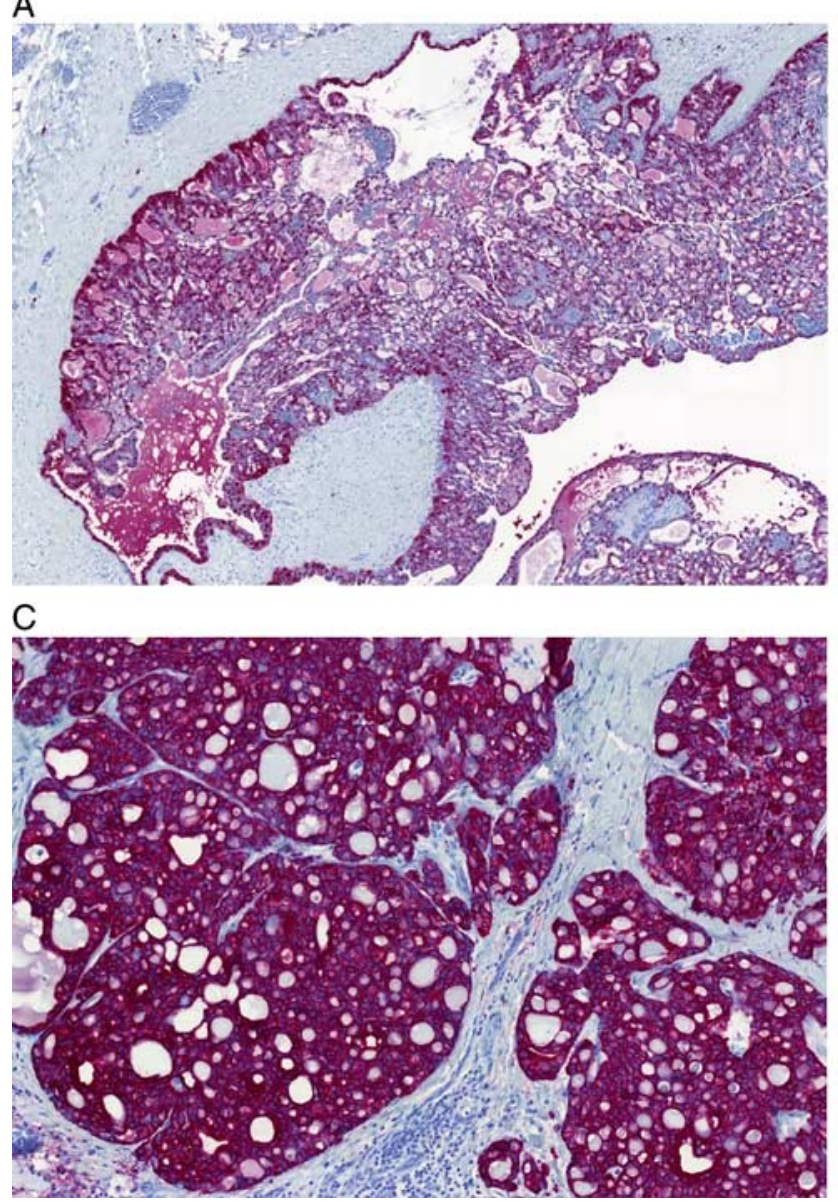

B

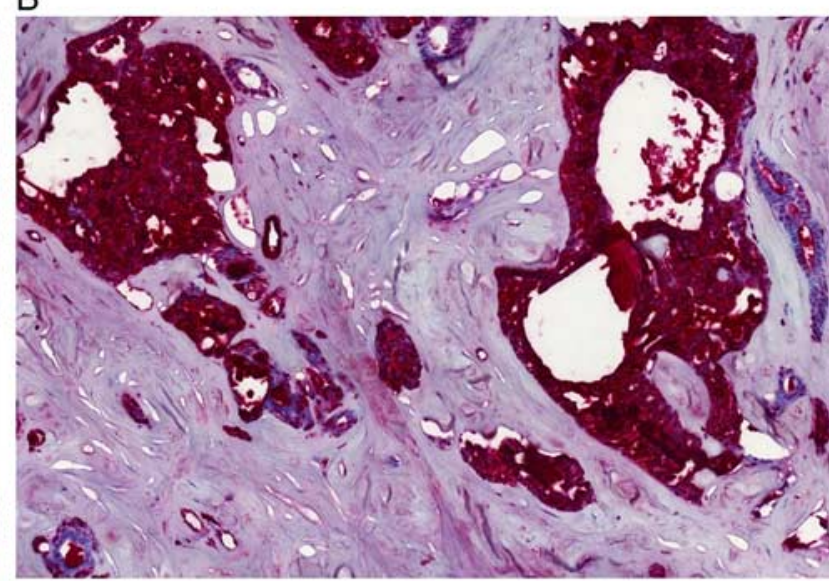

D

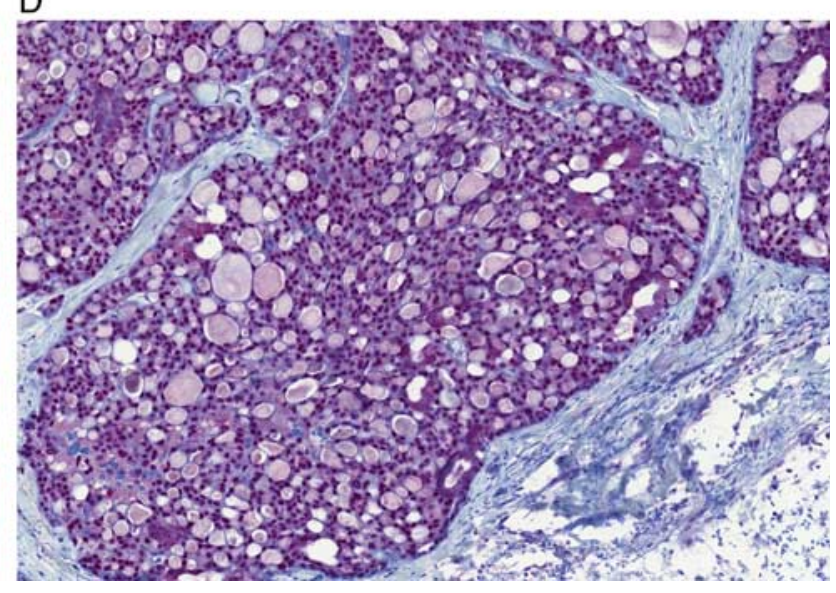

FIGURE 6. SC cases were all positive for S100 protein (A), mammaglobin (B), typically in strong and diffuse fashion (secretory material was also positive), and cytokeratin CK7 (C). SOX-10 positive nuclear expression is present (D).

carcinomas. NCOA4-RET fusions have been found in 2 SDCs. ${ }^{41}$ Both NCOA4-RET translocated SDCs were positive for androgen receptors, and the tumors progressed in spite of undergoing concurrent chemoradiation, combination chemotherapy, and dual androgen deprivation therapy. Both patients with NCOA4-RET translocation, however, benefited from $R E T$-targeted therapy. ${ }^{41}$

The treatment of SC has varied, ranging from simple excision to radical resection, neck dissection, adjuvant radiotherapy, and/or adjuvant systemic chemotherapy. $1,42,43$ For patients presenting with a locally advanced, recurrent, or metastatic disease, the treatment options are currently limited and mainly palliative. ${ }^{42,43}$ Therefore, SCs with ETV6-RET fusion translocation must be clearly distinguished from SCs with ETV6-NTRK3 translocation, because the drugs RXDX105 and LOXO 292, effective with various tumors driven with $R E T$ gene alterations, are being tested for the treatment. SCs with ETV6-RET translocation might respond much better to these drugs, whereas entrectinib and similar inhibitors of tyrosine kinases TRKA/B/C will probably be ineffective. ${ }^{44} 47$
In summary, a novel finding in our study has been the discovery of a subset of SC patients with ETV6-RET fusions who may benefit from RET-targeted therapy. Many salivary gland malignancies are still included in the group of adenocarcinomas not otherwise specified. We believe that detailed genomic profiling and NGS of a large cohort of these unspecified neoplasms may lead to the identification of novel gene fusions and driver mutations characterizing new clinically relevant subgroups of salivary gland carcinomas. This study highlights that further molecular analyses of salivary gland tumors are warranted and deserve special attention to identify new tumor types with possible therapeutic implications.

\section{ACKNOWLEDGMENTS}

The authors thank Alos Lucia, MD (Barcelona, Spain), Rychlý B, MD, PhD (Bratislava, Slovac Republic), Vazmitel M, MD, PhD (USA), Dana Cempirková, MD (Jindřichi̊v Hradec, Czech Republic), Ian Cook, MD (Salisbury, UK), and Tiziana Salviati, MD (Italy) for submitting the cases and clinical information about the patients. 


\section{REFERENCES}

1. Skalova A, Vanecek T, Sima R, et al. Mammary analogue secretory carcinoma of salivary glands, containing the ETV6-NTRK3 fusion gene: a hitherto undescribed salivary gland tumor entity. Am J Surg Pathol. 2010;34:599-608.

2. Tognon C, Knezevich SR, Huntsman D, et al. Expression of the ETV6-NTRK3 gene fusion as a primary event in human secretory breast carcinoma. Cancer Cell. 2002;2:367-376.

3. Li Z, Tognon CE, Godinho FJ, et al. ETV6-NTRK3 fusion oncogene initiates breast cancer from committed mammary progenitors via activation of AP1 complex. Cancer Cell. 2007;12:542-558.

4. Skálová A, Bell D, Bishop JA, et al. Secretory carcinoma. In: ElNaggar A, Chan JKC, Grandis JR, Takata T, Slootweg PJ, eds. World Health Organization (WHO) Classification of Head and Neck Tumours, 4th ed. Lyon, France: IARC Press; 2017:177-178.

5. Dogan S, Wang L, Ptashkin RN, et al. Mammary analog secretory carcinoma of the thyroid gland: a primary thyroid adenocarcinoma harboring ETV6-NTRK3 fusion. Mod Pathol. 2016;29:985-995.

6. Reynolds S, Shaheen M, Olson G, et al. A case of primary mammary analog secretory carcinoma (MASC) of the thyroid masquerading as papillary thyroid carcinoma: potentially more than a one off. Head Neck Pathol. 2016;10:405-413.

7. Dettloff J, Seethala RR, Stevens TM, et al. Mammary analog secretory carcinoma (MASC) involving the thyroid gland: a report of the first 3 cases. Head Neck Pathol. 2007;11:266-267.

8. Stevens TM, Kovalovsky AO, Velosa C, et al. Mammary analog secretory carcinoma, low-grade salivary duct carcinoma, and mimickers: a comparative study. Mod Pathol. 2015;28:1084-1100.

9. Hyrcza MD, Ng T, Crawford RI. Detection of the ETV6-NTRK3 translocation in cutaneous mammary-analogue secretory carcinoma. Diagn Histopathol. 2015;21:481-484.

10. Bishop JA, Taube JM, Su A, et al. Secretory carcinoma of the skin harboring ETV6 gene fusions. A cutaneous analogue to secretory carcinomas of the breast and salivary glands. Am J Surg Pathol. 2017;41:62-66

11. Lurquin E, Jorissen M, Debiec-Rychter M, et al. Mammary analogue secretory carcinoma of the sinus ethmoidalis. Histopathology. 2015;67:749-751.

12. Rubin BP, Chen CJ, Morgan TW, et al. Congenital mesoblastic nephroma $\mathrm{t}(12 ; 15)$ is associated with ETV6-NTRK3 gene fusion: cytogenetic and molecular relationship to congenital (infantile) fibrosarcoma. Am J Pathol. 1998;153:1451-1458.

13. Knezevich SR, Garnett MJ, Pysher TJ, et al. ETV6- NTRK3 gene fusions and trisomy 11 establish a histogenetic link between mesoblastic nephroma and congenital fibrosarcoma. Cancer Res. 1998;15:5046-5048.

14. Kralik JM, Kranewitter W, Boesmueller H, et al. Characterization of a newly identified ETV6-NTRK3 fusion transcript in acute myeloid leukemia. Diagn Pathol. 2011;6:19.

15. Alassiri AH, Ali RH, Shen Y, et al. ETV6-NTRK3 is expressed in a subset of ALK-negative inflammatory myofibroblastic tumor. Am J Surg Pathol. 2016;40:1051-1061.

16. Brenca M, Rossi S, Polano M, et al. Transcriptome sequencing identifies ETV6-NTRK3 as a gene fusion involved in GIST. J Pathol. 2016;238:543-549.

17. Leeman-Neill RJ, Kelly LM, Liu P, et al. ETV6-NTRK3 is a common chromosomal rearrangement in radiation-associated thyroid cancer. Cancer. 2014;120:799-807.

18. Seethala RR, Chiosea SI, Liu CZ, et al. Clinical and morphological features of $E T V 6-N T R K 3$ translocated papillary thyroid carcinoma in an adult population without radiation exposure. Am J Surg Pathol. 2017;41:446-457.

19. Griffith C, Seethala R, Chiosea SI. Mammary analogue secretory carcinoma: a new twist to the diagnostic dilemma of zymogen granule poor acinic cell carcinoma. Virchows Arch. 2011;459: $117-118$

20. Fehr A, Loning T, Stenman G. Mammary analogue secretory carcinoma of the salivary glands with ETV6-NTRK3 gene fusion. Letter to the editor. Am J Surg Pathol. 2011;35:1600-1602.

21. Connor A, Perez-Ordoñez B, Shago M, et al. Mammary analog secretory carcinoma of salivary gland origin with the ETV6 gene rearrangement by FISH: expanded morphologic and immunohistochemical spectrum of a recently described entity. Am J Surg Pathol. 2012;36:27-34.

22. Chiosea SI, Griffith C, Assad A, et al. The profile of acinic cell carcinoma after recognition of mammary analog secretory carcinoma. Am J Surg Pathol. 2012;36:343-350.

23. Majewska H, Skálová A, Stodulski D, et al. Mammary analogue secretory carcinoma of salivary glands: first retrospective study of a new entity in Poland with special reference to ETV6 gene rearrangement. Virchows Arch. 2015;466:245-254.

24. Pinto A, Nosé V, Rojas C, et al. Searching for mammary analogue secretory carcinoma among their mimicks. Mod Pathol. 2014;27:30-37.

25. Bishop JA. Unmasking MASC: bringing to light the unique morphologic, immunohistochemical and genetic features of the newly recognized mammary analogue secretory carcinoma of salivary glands. Head Neck Pathol. 2013;7:35-39.

26. Skalova A, Vanecek T, Simpson RHW, et al. Mammary analogue secretory carcinoma of salivary glands. Molecular analysis of 25 ETV6 gene rearranged tumors with lack of detection of classical ETV6-NTRK3 fusion transcript by standard rt-pcr: report of 4 cases harboring ETV6-X gene fusion. Am J Surg Pathol. 2016;40:3-13.

27. Ito $\mathrm{Y}$, Ishibashi $\mathrm{K}$, Masaki A, et al. Mammary analogue secretory carcinoma of salivary glands: a clinicopathological and molecular study including 2 cases harboring ETV6-X fusion. Am J Surg Pathol. 2015;39:602-610.

28. Murphy DA, Ely HA, Shoemaker R, et al. Detecting gene rearrangements in patient populations through a 2-step diagnostic test comprised of rapid IHC enrichment followed by sensitive next-generation sequencing. Appl Immunohistochem Mol Morphol. 2017;25:513-523.

29. Viswanatha DS, Foucar K, Berry BR, et al. Blastic mantle cell leukemia: an unusual presentation of blastic mantle cell lymphoma. Mod Pathol. 2000;13:825-833.

30. Gaffney R, Chakerian A, O'Connell JX, et al. Novel fluorescent ligase detection reaction and flow cytometric analysis of SYT-SSX fusions in synovial sarcoma. J Mol Diagn. 2003;5:127-135.

31. Antonescu CR, Kawai A, Leung DH, et al. Strong association of SYT-SSX fusion type and morphologic epithelial differentiation in synovial sarcoma. Diagn Mol Pathol. 2000;9:1-8.

32. Bourgeois JM, Knezevich SR, Mathers JA, et al. Molecular detection of the ETV6-NTRK3 gene fusion differentiates congenital fibrosarcoma from other childhood spindle cell tumors. Am J Surg Pathol. 2000;24:937-946.

33. Su RJ, Jonas BA, Welborn J, et al. Chronic eosinophilic leukemia, NOS with $t(5 ; 12)(\mathrm{q} 31 ; \mathrm{p} 13) /$ ETV6-ACSL6 gene fusion: a novel variant of myeloid proliferative neoplasm with eosinophilia. Hum Pathol. 2016;5:6-9.

34. Drilon A, Siena S, Ou SI, et al. Safety and antitumor activity of the multitargeted Pan-TRK, ROS1, and ALK inhibitor Entrectinib: Combined results from two phase I trials ALKA-372-001 and STARTRK-1. Cancer Discov. 2017;7:400-407.

35. Drilon A, Li G, Dogan S, et al. What hides behind the MASC: clinical response and acquired resistance to entrectinib after ETV6-NTRK3 identification in a mammary analogue secretory carcinoma (MASC). Ann Oncol. 2016;27:920-926.

36. Tannenbaum-Dvir S, Glade Bender JL, Church AJ, et al. Characterization of a novel fusion gene EML4-NTRK3 in a case of recurrent congenital fibrosarcoma. Cold Spring Harb Mol Case Stud. 2015;1: a000471.

37. Tirado CA, Siangchin K, Shabsovich DS, et al. A novel three-way rearrangement involving ETV6 (12p13) and $A B L 1(9 \mathrm{q} 34)$ with an unknown partner on $3 \mathrm{p} 25$ resulting in a possible $E T V 6-A B L 1$ fusion in a patient with acute myeloid leukemia: a case report and a review of the literature. Biomark Research. 2016;4:16.

38. Abe A, Yamamoto Y, Iba S, et al. ETV6-LPXN fusion transcript generated by $\mathrm{t}(11 ; 12)(\mathrm{q} 12.1 ; \mathrm{p} 13)$ in a patient with relapsing acute myeloid leukemia with NUP98-HOXA9. Genes Chromosomes Cancer. 2016;55:242-250.

39. Garcia DR, Arancibia AM, Ribeiro RC, et al. Intrachromosomal amplification of chromosome 21 (iAMP21) detected by ETV6/RUNX1 FISH screening in childhood acute lymphoblastic leukemia: a case report. Rev Bras Hematol Hemoter. 2013;35:369-371. 
40. Strehl S, Nebral K, König M, et al. ETV6-NCOA2: a novel fusion gene in acute leukemia associated with coexpression of T-lymphoid and myeloid markers and frequent NOTCH1 mutations. Clin Cancer Res. 2008;14:977-983.

41. Wang K, Russell JS, McDermott JD, et al. Profiling of 149 salivary duct carcinomas, carcinoma ex pleomorphic adenomas, and adenocarcinomas, not otherwise specified reveals actionable genomic alterations. Clin Cancer Res. 2016;22:6061-6068.

42. Skálová A, Vanecek T, Majewska H, et al. Mammary analogue secretory carcinoma of salivary glands with high-grade transformation: report of 3 cases with the ETV6-NTRK3 gene fusion and analysis of TP53, betacatenin, EGFR, and CCND1 genes. Am J Surg Pathol. 2014;38:23-33.

43. Luo W, Lindley SW, Lindley PH, et al. Mammary analog secretory carcinoma of salivary gland with high-grade histology arising in palate, report of a case and review of literature. Int J Clin Exp Pathol. 2014;7:9008-9022.

44. Li GG, Somwar R, Joseph J, et al. Antitumor activity of RXDX-105 in multiple cancer types with RET rearrangements or mutations. Clin Cancer Res. 2017;23:2981-2990.

45. Sabari JK, Siau ED, Drilon A. Targeting RET-rearranged lung cancers with multikinase inhibitors. Oncoscience. 2017;4:23-24.

46. Chi HT, Ly BT, Kano Y, et al. ETV6-NTRK3 as a therapeutic target of small molecule inhibitor PKC412. Biochem Biophys Res Commun. 2012;429:87-92.

47. Tognon CE, Somasiri AM, Evdokimova VE, et al. ETV6-NTRK3mediated breast epithelial cell transformation is blocked by targeting the IGF1R signaling pathway. Cancer Res. 2011;71: $1060-1070$. 